\title{
Diversity and ecological aspects of aquatic insect communities from montane streams in southern Brazil
}

\author{
Diversidade e aspectos ecológicos de comunidades de insetos aquáticos em \\ riachos de uma regiáo montanhosa, sul do Brasil
}

Bruna Marmitt Braun ${ }^{1}$, Mateus Marques Pires ${ }^{2}$, Carla Bender Kotzian ${ }^{1}$ and Marcia Regina Spies ${ }^{3}$

${ }^{1}$ Programa de Pós-graduação em Biodiversidade Animal, Departamento de Biologia, Centro de Ciências Naturais e Exatas, Universidade Federal de Santa Maria - UFSM, Faixa de Camobi,

Km 9, CEP 97105-900, Santa Maria, RS, Brazil

e-mail: brumbraun@gmail.com; modri_zralok@hotmail.com

${ }^{2}$ Programa de Pós-graduação em Biologia, Centro de Ciências da Saúde, Universidade do Vale do Rio dos Sinos - UNISINOS, Avenida Unisinos, 950, CEP 93022-000, São Leopoldo, RS, Brazil e-mail: marquespiresm@gmail.com

${ }^{3}$ Universidade Federal do Pampa - UNIPAMPA, Av. Antônio Trilha, 1847, CEP 97300-000, São Gabriel, RS, Brazil e-mail: marciaspies@gmail.com

\begin{abstract}
Aims: In this study, the diversity of Ephemeroptera, Plecoptera, Trichoptera and Coleoptera communities was surveyed in the Toropi River basin, a watershed localized in a slope region, in southernmost Brazil. The influence of some local abiotic factors on the most common genera was also analyzed. Methods: Samplings were conducted at 40 sites in $1^{\text {st }}-4^{\text {th }}$ order streams, along a short elevation gradient $(70-500 \mathrm{~m})$, with a Surber sampler. Water physico-chemical factors, as well as substrate type, were obtained at each site. Results: At all, 5,320 specimens were collected, belonging to 18 families and 52 genera. The caddisflies Austrotinodes and Celaenotrichia, and an undescribed Elmidae, Genus M, are new records for the region. The caddisfly Smicridea was the most frequent genus in the study area. The mayflies Camelobaetidius, Paracloeodes and Americabaetis were influenced by stream order. Smicridea was related to air temperature, while the mayfly Thraulodes was influenced by high levels of electrical conductivity. Conclusions: The high diversity found in the study area, compared to other Brazilian regions, reflects the environmental heterogeneity in the region. These data show that hydrographic basins in slope areas from extreme Southern Brazil sustain high levels of diversity of aquatic insect communities.
\end{abstract}

Keywords: abiotic factors, environmental heterogeneity, spatial distribution, altitudinal gradient, Neotropical Region.

Resumo: Objetivos: Neste estudo a diversidade de comunidades de Ephemeroptera, Plecoptera, Trichoptera e Coleoptera foi analisada em riachos da Bacia do Rio Toropi, localizada em uma regiáo de encosta, no extremo sul do Brasil. A influência de alguns fatores abióticos sobre os gêneros mais frequentes também foi analisada. Métodos: As coletas foram realizadas em 40 locais, em riachos de $1^{\text {a }}$ a $4^{\text {a }}$ ordem, ao longo de um gradiente altitudinal curto (70-500 m), com amostrador Surber. Fatores físico-químicos da água, bem como o tipo de substrato, foram medidos em cada local. Resultados: Ao todo, 5320 exemplares foram coletados, atribuídos a 18 famílias e 52 gêneros. Os tricópteros Austrotinodes, Celaenotrichia e um elmídeo não descrito, Gênero M, são ocorrências novas no estado. O tricóptero Smicridea foi o gênero mais freqüente na área de estudo como um todo. Os efemerópteros Camelobaetidius, Paracloeodes e Americabaetis foram influenciados pela ordem dos rios. Smicridea foi relacionado com a alta temperatura do ar, enquanto o efemeróptero Thraulodes foi influenciado pelo aumento da condutividade elétrica. Conclusóes: A alta diversidade encontrada na regiáo estudada, comparada a de outras regiōes brasileiras, é resultado da heterogeneidade ambiental da região de amostragem. Estes dados mostram que rios da encosta do Planalto Meridional são áreas que devem ser preservadas, pois possuem uma rica comunidade de insetos aquáticos.

Palavras-chave: fatores abióticos, heterogeneidade ambiental, distribuição espacial, gradiente altitudinal, Região Neotropical. 


\section{Introduction}

Rivers and streams are one of the most threatened ecosystems worldwide, due to human pressure on water sources (Allan and Castillo, 2007; Maloney et al., 2011). In southernmost Brazil (Rio Grande do Sul State, RS), rivers are commonly used in agriculture, especially for irrigated rice fields (Primel et al., 2005). Additionally, man-made ponds are frequent in montane areas, mainly in small properties for agricultural and domestic purposes (Beskow, 1984; Pires et al., 2013). In other words, the rich hydrographic network of the region is being converted to a mosaic of lentic and semi-lotic environments, affecting the lotic-dependent aquatic fauna. Besides, a recent state law (no 94, December $16^{\text {th }} 2008$ ) allowed stream damming for reservoir construction without demanding of environmental assessment. Thus, it is very important to survey aquatic insect community diversity in rivers and streams in Rio Grande do Sul, before many of them are extirpated, hindering obtain data related to the protection of lotic ecosystems environmental integrity.

Aquatic insects such as Ephemeroptera, Plecoptera and Trichoptera (EPT), as well as some coleopteran (hereafter C) families such as Elmidae and Psephenidae, are important components in lotic ecosystems, and generally predominate at these environments, for they are diverse and broad distributed insects. Many of these insects are sensitive to environmental perturbations and are considered indicators of water quality. The occurrence of diverse EPT larval communities, and also of elmids and psephenids, is associated with low-polluted and well-oxygenated streams (Rosenberg and Resh, 1993). They can also be associated to well preserved riparian vegetation (Bispo et al., 2006). Additionally, abiotic factors related to streams environmental condition, such as water temperature, electrical conductivity, $\mathrm{pH}$, and current velocity are important drivers of their communities (Fernandez and Fonseca, 2001; Buss et al., 2004; Bispo et al., 2006; Merritt et al., 2008). Thus, the presence of EPTC may reflect the integrity of the entire aquatic insect community (Crisci-Bispo et al., 2007).

In Brazil, studies on diversity of EPTC were conducted mainly in tropical and subtropical streams, where they are found inhabiting streams in both plateau and slope areas (e.g. Bispo and Oliveira, 2007; Gonçalves and Menezes, 2011; Paciencia et al., 2011; Segura et al., 2012). The most important factors affecting this fauna are stream order, rainfall, altitude and water current (Oliveira et al., 1997; Bispo et al., 2006; Bispo and Oliveira, 2007). Additionally, substrate plays important role in structuring their communities. EPT, as well as Elmidae and Psephenidae, are commonly found in stony-bottom streams (Bispo and Oliveira, 2007; Domínguez and Fernández, 2009). However, in streams located in colder temperate regions, and with regular rainfall, like in southernmost Brazil (Nimer, 1990; Maluf, 2000), little is known about their diversity, and, especially, about the influence of environmental factors on genera occurrence and composition. Many studies have been conducted with macroinvertebrate identification at family level (e.g., Pereira and De Luca, 2003; Buckup et al., 2007; Milesi et al., 2009), while others deals with EPT or were restricted to certain groups (e.g., Hepp et al. (2010, 2013); Salvarrey et al. (2014) for EPT; Spies et al. (2006) for Trichoptera; Siegloch et al. (2008) for Ephemeroptera; Salvarrey et al. (2014) for Elmidae).

This study presents the results of an inventory of EPTC genera in montane streams from southern Brazil. Also the overall EPTC diversity is compared with those of other Brazilian regions. Considering that montane areas can reach up to $500 \mathrm{~m}$ in the study region (Robaina et al., 2010), and that many abiotic factors are modulated by riverine longitudinal gradient (Vannote et al., 1980), the influence of abiotic factors on the most frequent EPTC genera was also analyzed. The relationship of the abiotic factors with the environmental integrity of the streams studied was also analyzed. Thus, this study also provides important information for stream conservation and environmental assessment programs.

\section{Material and Methods}

\subsection{Study area}

The Toropi River basin is located in extreme southern Brazil (Rio Grande do Sul State, RS) $\left(28^{\circ} 30^{\prime}-31^{\circ} \mathrm{S} ; 53^{\circ} 30^{\prime}-57^{\circ} \mathrm{W}\right)$, covering a $47,740 \mathrm{~km}^{2}$ catchment area. The headwaters are located in the Southern Plateau (Planalto Meridional), reaching ca. $500 \mathrm{~m}$ altitude, although most streams run through the slope areas. The Toropi is a $6^{\text {th }}$ order river near the mouth, and flows into the Ibicuí River, in a lowland region, the Central Depression (Depressão Central, ca. $70 \mathrm{~m}$ altitude, Hundertmarck and Miorin, 2001). Through its course, the Toropi River runs through basaltic rocks in the Plateau, a mixture of sedimentary rocks and basalt in the slope, and 
alluvial-origin sands in the lowland (Robaina et al., 2010). The climate is characterized by regular rainfall through the year, with annual accumulated precipitation range of 1,250-2,000 $\mathrm{mm}$ (Silva et al., 2006; Buriol, 2007). The mean temperature in the warmest months is superior to $22^{\circ} \mathrm{C}$, and in the coldest ones, near $13^{\circ} \mathrm{C}$ (Maluf, 2000). The original vegetation in the region is located in a transitional zone between Seasonal Decidual Forest (Atlantic Forest biome) in the slope, and Savannah (grassland) in the Central Depression (Quadros and Pillar, 2001; Kilca and Longhi, 2011). Nowadays, most part of the original landscape was converted to agricultural activities, mainly rice fields in the floodplains (Pedron et al., 2006).

\subsection{Sampling sites and abiotic factors}

Sampling was conducted in October and November 2010, when droughts and floods are scarce in the region (Maluf, 2000), a suitable period for macroinvertebrate sampling (Bispo et al., 2001). Samplings took place in 40 sites (Figure 1), in $1^{\text {st }}$ to $4^{\text {th }}$ order streams, distributed along the altitudinal gradient from the Plateau to the Depression (ca. $500 \mathrm{~m})$. All sites had riparian vegetation in both stream banks. The altitude was taken with a GPS (Garmin model), and stream order, through consultation to cartographic charts (scale 1:50,000). Air and water temperatures (AT and WT, respectively, alcohol $0-50^{\circ} \mathrm{C}$ thermometer), mean depth $(\mathrm{m})$ and water current velocity (WC, floating method) were taken at each site. Stream bed sediment grain size was determined based on Wentworth scale, through calculation of \% gravel directly at each site and the rest in the lab. Dissolved oxygen (DO, mg.l $\left.\mathrm{l}^{-1}\right)$, $\mathrm{pH}\left(\mathrm{mol} . \mathrm{dm}^{-3}\right)$, electrical conductivity $\left(\mathrm{EC}, \mu \mathrm{S} . \mathrm{cm}^{-1}\right)$ and biochemical oxygen demand ( $\mathrm{DBO}, \mathrm{mg} \mathrm{O}_{2} \cdot \mathrm{l}^{-1}$ ) were taken with a multiparameter probe Concentration of calcium and iron ions (mg. $\left.{ }^{-1}\right)$ were also measured (atomic absorption spectrophotometer). Data on accumulated precipitation $(\mathrm{mm})$ and mean month temperature $\left({ }^{\circ} \mathrm{C}\right)$ for the study region were taken from the Departamento de Fitotecnia of UFSM.

\subsection{Sampling methods and identification}

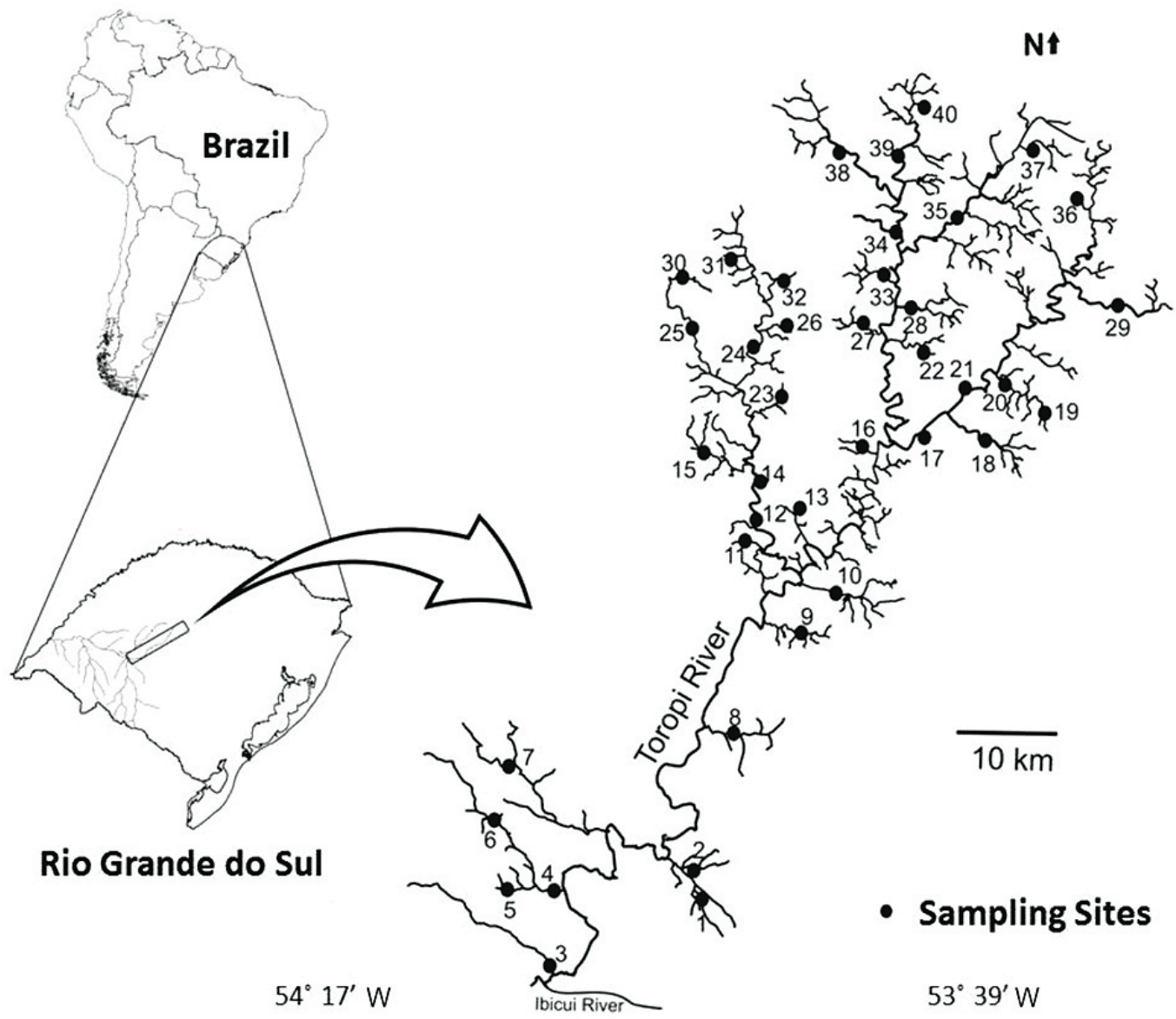

Figure 1. Location of the study area and the sampling sites. 
Samplings were carried out preferably in streams margins, at less than $1 \mathrm{~m}$ depth sites. For the collection a Surber sampler was used (area $=0.1 \mathrm{~m}^{2}$; mesh $=0.25 \mathrm{~mm}$ ). Three subsamples were taken at each site, distant each other at least $10 \mathrm{~m}$, and posteriorly pooled in one single sample. The individuals collected were fixed with $70 \%$ ethyl alcohol.

The specimens were identified up to genus level, through consultation to specialized bibliography (Angrisano and Korob, 2001; Lecci and Froehlich, 2007; Mariano and Froehlich, 2007; Domínguez and Fernández, 2009; Segura et al., 2011). Voucher specimens are deposited in the Coleção de Macroinvertebrados Aquáticos of the Departamento de Biologia of the UFSM.

\subsection{Data analysis}

In order to facilitate the comparison of EPTC diversity patterns with subtropical and tropical areas of the country, a brief inventory on genera richness per group studied (Ephemeroptera, Plecoptera, Trichoptera, Elmidae and Psephenidae) is provided, based on previous community studies selected from the literature, conducted with similar sampling effort in other regions of the Brazilian territory.

Community diversity was analyzed in relation to richness $(\mathrm{S})$, number of individuals $(\mathrm{N})$, relative frequency $(\%)$ and dominance. The accumulated richness in the study area was estimated through the collector's curve, obtained after the generation of 500 curves by random addition of samples. The program EstimateS 8.0 (Colwell, 2006) was used for this analysis.

The influence of abiotic factors on the communities was assessed by a Redundancy Analysis (RDA; Legendre and Legendre, 1998). For the analysis, the following variables were used: stream order, altitude, AT, WT, WC, pH, DO, EC, DBO, calcium and iron concentration, and granulometric composition (Sand, Gravel and Mud). The forward stepwise procedure was chosen to select the most important variables for the model $(\mathrm{p}<0.05$, after Monte Carlo randomizations). Variables with inflation factor $>20$ were excluded from the analysis (ter Braak and Šmilauer, 2002). The variables retained in the model were EC, AT and stream order. Rare taxa ( $<10$ individuals) were excluded from the biotic matrix, which was Hellinger-transformed (Legendre and Gallagher, 2001). Monte Carlo randomization test (999 permutations) was used to assess the statistical significance of the canonical axes generated (ter Braak and Šmilauer, 2002).

\section{Results}

Overall, 5,320 individuals were collected, belonging to 18 families and 52 genera (Table 1). The collector's curve did not reach the asymptote but showed a trend to stabilization (Figure 2), suggesting that a small increase in richness may be achieved with additional samplings. Ephemeroptera was represented by four families, Plecoptera, by two, and Trichoptera, by ten. The most diverse families were Elmidae (eight genera), followed by Leptohyphidae (six genera). The most abundant genera were Smicridea McLachlan, 1871, Americabaetis Kluge, 1992, Thraulodes Ulmer, 1920 and Baetodes Needham and Murphy, 1924, which represented $59 \%$ of the total of individuals (Table 1). The most well distributed genera were Americabetis and Neoelmis Musgrave, 1935, which occurred in more than $90 \%$ of the sites. Seventeen genera were rare, occurring at two sites at most (Table 1). Table 2 compares genera richness per group studied (Ephemeroptera, Plecoptera, Trichoptera, Elmidae and Psephenidae) with inventories conducted in other regions of Brazil.

\subsection{Influence of abiotic factors on community composition}

The model generated by the RDA was significantly different from chance $(\mathrm{F}=2.62$; $\mathrm{p}=0.005)$. The two first axes summarized $16 \%$ of the variance in genera abundance data, and explained $89 \%$ of their relation with abiotic factors measured (Table 3). The first axis was negatively correlated with AT and EC, while the second one, positively correlated with stream order and EC (Figure 3a; Table 4). In general, the first axis of the ordination segregated sites in relation to their altitudinal variation (from $0-300 \mathrm{~m}$ to $300-500 \mathrm{~m}$ ). The second axis summarized part of the environmental variation of samples, segregating samples in relation to EC and stream order (Figure 3a).

Few relationships of some taxa with abiotic factors could be derived in the ordination diagram (Figure 3b). Smicridea was positively related to AT. Thraulodes was positively to EC, while Camelobaetidius Demoulin, 1966 and Paracleodes, negatively. Americabaetis and Paracloeodes were negatively related to stream order.

\section{Discussion}

The collector's curve did not reach the asymptote, but tended to stabilization. Although collections were restricted to one period only, the sampling season (spring months) favored the occurrence 
Table 1. Composition, number of individuals $(\mathrm{N})$, frequency (\%) and number of occurrences in relation to the total number of sampling sites (NO) of Plecoptera, Ephemeroptera, Trichoptera and Coleoptera (Elmidae and Psephenidae) genera in the Toropi River basin, southern Brazil. ( $\mathrm{Ab}=$ genera name abreviation).

\begin{tabular}{|c|c|c|c|c|c|c|}
\hline Families & $A b$ & Genus & & $\mathbf{N}$ & $\%$ & NO \\
\hline \multirow[t]{6}{*}{ Baetidae } & g12 & Americabaetis & Kluge, 1992 & 693 & 13.02 & 32 \\
\hline & $g 13$ & Baetodes & Needham \& Murphy, 1924 & 512 & 9.6 & 14 \\
\hline & g14 & Callibaetis & Eaton, 1881 & 11 & 0.2 & 6 \\
\hline & g15 & Camelobaetidius & Demoulin, 1966 & 210 & 3.9 & 21 \\
\hline & g16 & Cloeodes & Traver, 1938 & 75 & 1.4 & 14 \\
\hline & g17 & Paracloeodes & Day, 1955 & 85 & 1.59 & 20 \\
\hline Caenidae & g18 & Caenis & Stephens, 1835 & 316 & 5.93 & 21 \\
\hline \multirow[t]{6}{*}{ Leptohyphidae } & & Haplohyphes & Molineri, 2001 & 4 & 0.07 & 4 \\
\hline & & Leptohyphes & Eaton, 1882 & 6 & 0.11 & 5 \\
\hline & & Leptohyphodes & Ulmer, 1920 & 4 & 0.07 & 3 \\
\hline & & Traveryphes & Molineri, 2001 & 8 & 0.15 & 5 \\
\hline & & Tricorythodes & Ulmer, 1920 & 6 & 0.11 & 2 \\
\hline & g19 & Tricorythopsis & Traver, 1958 & 143 & 2.68 & 12 \\
\hline \multirow[t]{5}{*}{ Leptophlebiidae } & g20 & Askola & Peters, 1969 & 11 & 0.2 & 2 \\
\hline & g21 & Farrodes & Peters, 1971 & 41 & 0.77 & 13 \\
\hline & & Leentvaaria & Demoulin, 1966 & 2 & 0.03 & 2 \\
\hline & g21 & Thraulodes & Ulmer, 1920 & 548 & 10.3 & 19 \\
\hline & & Ulmeritoides & Traver, 1956 & 2 & 0.03 & 1 \\
\hline \multirow[t]{3}{*}{ Gripopterygidae } & g1 & Tupiperla & Froehlich, 1969 & 37 & 0.69 & 16 \\
\hline & g2 & Paragripopteryx & Enderlein, 1909 & 142 & 2.66 & 23 \\
\hline & & Gripopteryx & Pictet, 1841 & 8 & 0.15 & 4 \\
\hline \multirow{2}{*}{ Perlidae } & g3 & Anacroneuria & Klapálek, 1909 & 71 & 1.33 & 15 \\
\hline & & Kempnyia & Klapálek, 1914 & 2 & 0.03 & 2 \\
\hline Calamoceratidae & g4 & Phylloicus & Müller, 1880 & 28 & 0.52 & 7 \\
\hline Ecnomidae & & Austrotinodes & Schmid, 1955 & 1 & 0.01 & 1 \\
\hline \multirow[t]{2}{*}{ Glossosomatidae } & & Protoptila & Banks, 1904 & 8 & 0.15 & 3 \\
\hline & g5 & Itaura & Müller, 1888 & 151 & 2.83 & 20 \\
\hline Helicopsychidae & & Helicopsyche & Siebold, 1856 & 4 & 0.07 & 2 \\
\hline Hidrobiosidae & & Atopsyche & Banks, 1905 & 5 & 0.09 & 2 \\
\hline \multirow[t]{2}{*}{ Hydropsychidae } & g7 & Leptonema & Guérin, 1843 & 64 & 1.2 & 23 \\
\hline & g6 & Smicridea & McLachlan, 1871 & 1380 & 25.93 & 6 \\
\hline \multirow[t]{6}{*}{ Hydroptilidae } & & Celaenotrichia & Mosely, 1934 & 1 & 0.01 & 1 \\
\hline & & Leucotrichia & Mosely, 1934 & 1 & 0.01 & 1 \\
\hline & & Leucotrichini & Mosely, 1934 & 2 & 0.03 & 2 \\
\hline & g8 & Metrichia & Ross, 1938 & 20 & 0.37 & 5 \\
\hline & g9 & Neotrichia & Morton, 1905 & 13 & 0.24 & 7 \\
\hline & & Oxyethira & Eaton, 1873 & 1 & 0.01 & 1 \\
\hline Leptoceridae & & Nectopsyche & Müller, 1879 & 2 & 0,03 & 2 \\
\hline Philopotamidae & g10 & Chimarra & Stephens, 1829 & 81 & 1.5 & 9 \\
\hline \multirow[t]{2}{*}{ Polycentropodidae } & g11 & Cyrnellus & Banks, 1913 & 5 & 0.09 & 4 \\
\hline & & Polyplectropus & Curtis, 1835 & 34 & 0.6 & 3 \\
\hline \multirow[t]{8}{*}{ Elmidae } & g23 & Heterelmis & Sharp, 1882 & 43 & 0.8 & 14 \\
\hline & g24 & Hexacylloepus & Hinton, 1940 & 79 & 1.4 & 17 \\
\hline & g25 & Hexanchorus & Sharp, 1882 & 8 & 0.15 & 4 \\
\hline & g26 & Macrelmis & Motschulsky, 1859 & 72 & 1.3 & 13 \\
\hline & g27 & Neoelmis & Musgrave, 1935 & 217 & 4.07 & 43 \\
\hline & & Phanocerus & Sharp, 1882 & 5 & 0.09 & 4 \\
\hline & & Xenelmis & Hinton, 1936 & 6 & 0.11 & 2 \\
\hline & & Genus M & & 1 & 0.01 & 2 \\
\hline Psephenidae & g29 & Psephenus & Hinton, 1936 & 151 & 2.83 & 8 \\
\hline
\end{tabular}




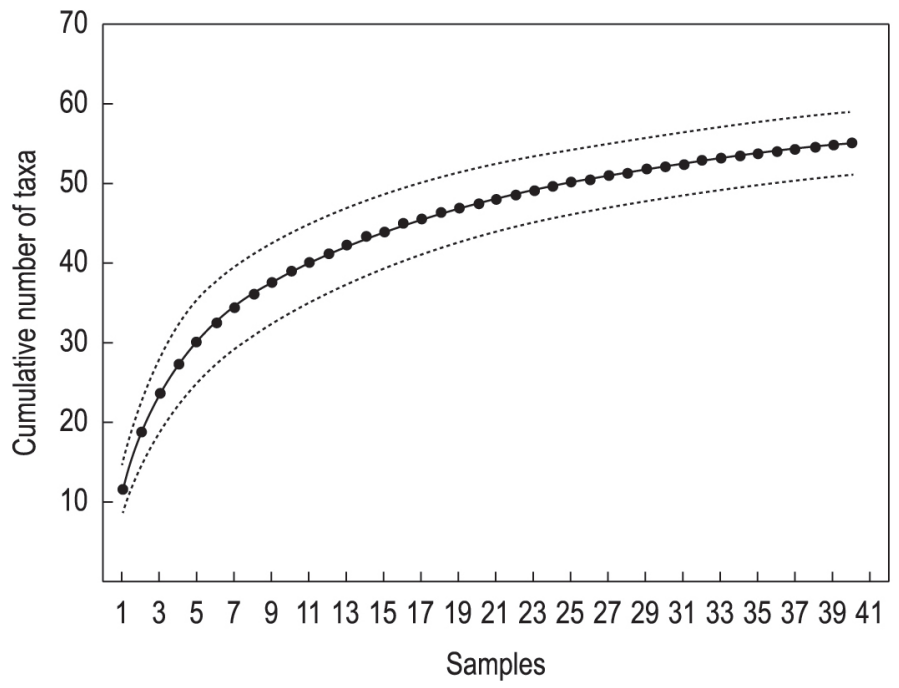

Figure 2. Cumulative richness of genera of Ephemeroptera, Plecoptera, Trichoptera and Coleoptera (Elmidae and Psephenidae) in the Toropi River basin, southern Brazil.

Table 2. Genera richness per group studied in other regions of the Brazilian territory, identified by location and climate $(S u b t=$ subtropical climate; Trop = tropical climate; Temp = temperate climate; Ephem = Ephemeroptera; Plec = Plecoptera; Tri $=$ Trichoptera; Elm = Elmidae; Psep = Psephenidae $)$.

\begin{tabular}{|c|c|c|c|c|c|c|c|c|}
\hline Author/year & Location & State & Climate & Ephem & Plec & Tri & Elm & Psep \\
\hline Hepp et al. (2013) & $1^{\text {st }}$ order streams & RS & Temp & 18 & 4 & 10 & - & - \\
\hline Benetti et al. (1998) & $1^{\text {st }}$ and $2^{\text {nd }}$ order streams & RS & Temp & - & - & - & 4 & 1 \\
\hline Siegloch et al. (2008) & Jacuí River basin & RS & Temp & 19 & - & - & - & - \\
\hline Spies et al. (2006) & Jacuí River basin & RS & Temp & - & - & 25 & - & - \\
\hline Segura et al. (2007) & Atlantic Forest & SP & Subt & - & - & - & 15 & - \\
\hline $\begin{array}{l}\text { Paula and Fonseca-Gessner } \\
\text { (2010) }\end{array}$ & $3^{\text {rd }}$ order streams & SP & Subt & 6 & 12 & 3 & 5 & - \\
\hline Paciencia et al. (2011) & Parque Intervalares & SP & Subt & 25 & 7 & 28 & - & - \\
\hline Baptista et al. (1998) & Macaé River & RJ & Subt & 16 & 5 & 16 & - & - \\
\hline Buss et al. (2002) & Guapimirim River & RJ & Subt & 14 & 17 & 3 & 8 & 1 \\
\hline Passos et al. (2003a) & Fazenda River & RJ & Subt & - & - & - & 7 & - \\
\hline Passos et al. (2003b) & Humaitá River & RJ & Subt & - & - & - & 7 & - \\
\hline Galdean et al. (2001) & São Francisco River basin & MG & Trop & 7 & - & 20 & - & - \\
\hline Romero et al. (2013) & $\begin{array}{l}\text { Paraná, Paraguay and São } \\
\text { Francisco basins }\end{array}$ & $\begin{array}{l}\text { PR, } \\
\text { GO, } \\
M G\end{array}$ & Trop & 28 & 5 & 32 & - & - \\
\hline Bispo et al. (2006) & Almas River basin & GO & Trop & 16 & 5 & 11 & - & - \\
\hline Bispo and Oliveira (2007) & Almas River basin & GO & Trop & 16 & 5 & 19 & - & - \\
\hline Barbosa et al. (2013) & $1^{\text {st }}-4^{\text {th }}$ order streams & GO & Trop & - & - & - & 13 & - \\
\hline Righi-Cavallaro et al. (2010) & Miranda River basin & MS & Trop & 26 & 1 & 22 & - & - \\
\hline Fidelis et al. (2008) & $1^{\text {st }}-3^{\text {rd }}$ order streams & AM & Trop & 9 & 8 & - & 7 & - \\
\hline this study & Toropi River basin & RS & Temp & 18 & 5 & 18 & 5 & 1 \\
\hline
\end{tabular}

of many insects which are recruited in the larval stage in warmer months (Bemvenuti, 1998). Yet, many taxa might have not been sampled due to stochastic events that affect macroinvertebrate communities, and could not be detected by sampling. Precipitation, for example, tends to interact with local factors, and destabilize the lotic ecosystem through alterations in stream flow and velocity, causing individuals drift (Bispo et al., 2001; Yokoyama et al., 2012).
The genera richness found in the study area (18 Ephemeroptera, five Plecoptera, 18 Trichoptera, eight Elmidae and one Psephenidae) might be considered high when compared to studies dealing with these taxa, conducted with similar sampling effort in subtropical regions of the country (Table 2). This result might have been determined by the location of the Toropi River basin in a slope region, a condition that enables the basin to host considerable environmental heterogeneity. 

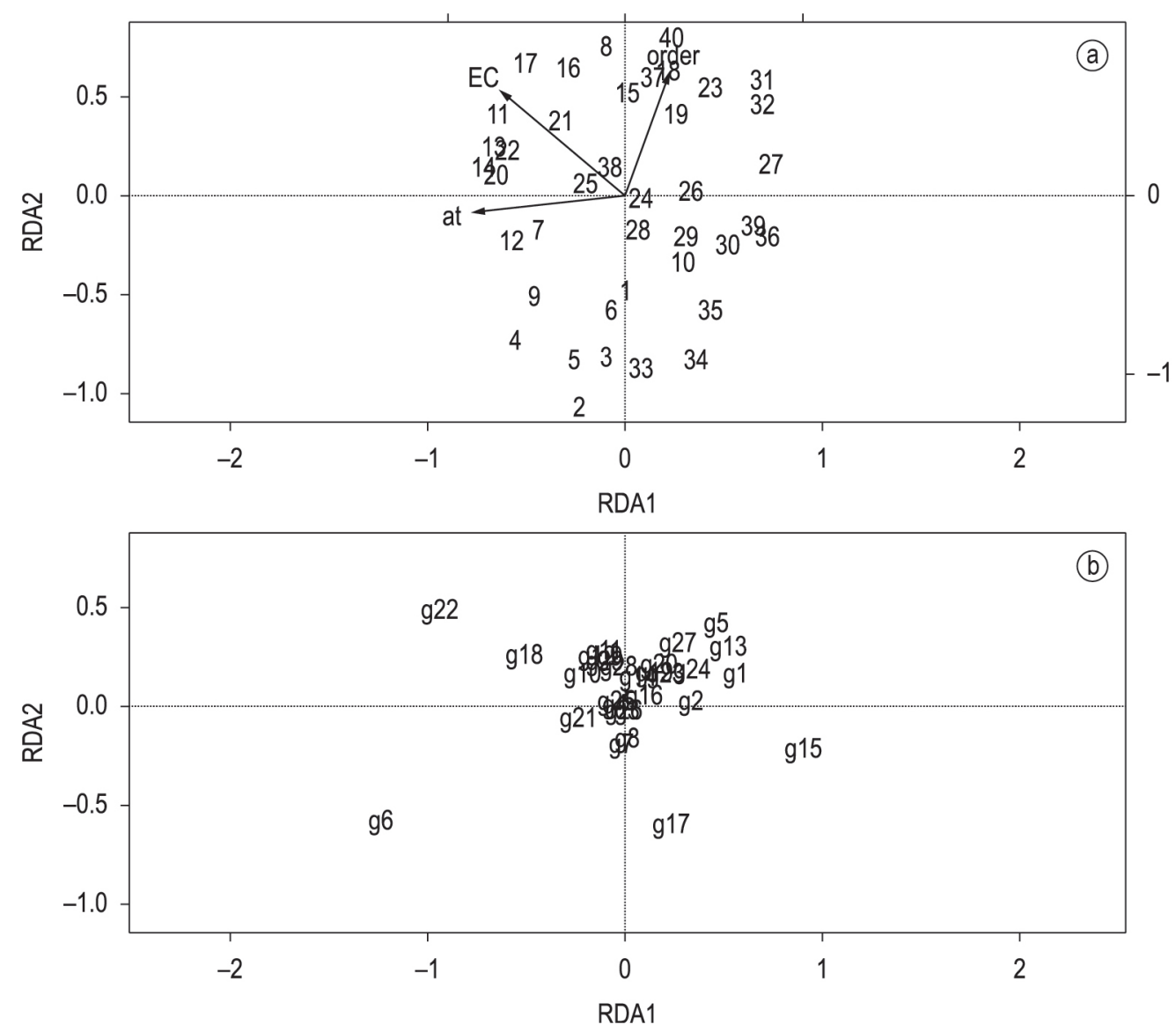

Figure 3. Ordination diagrams of the Redundancy Analysis of Ephemeroptera, Plecoptera, Trichoptera and Coleoptera (Elmidae and Psephenidae). a) biplot of abiotic factors and sampling sites; b) genera distribution in the canonical space. Subtitles for sites: see Table 1; subtitles for taxa: numeration follows the exact same order of taxa in Table 1 .

Table 3. Eigenvalues, taxon-environment correlation coefficients and explained cumulative percentage of variance of the first two axes of RDA of EPT and Coleoptera (Elmidae and Psephenidae) communities in the Toropi River basin, southern Brazil.

\begin{tabular}{lcc}
\hline \multicolumn{1}{c}{ Axes } & $\mathbf{1}$ & $\mathbf{2}$ \\
\hline Eigenvalues & 0.06 & 0.03 \\
Percentage of cumulative variance & & \\
data of taxa & 0.10 & 0.16 \\
taxa-enviroment relationship & 0.56 & 0.89 \\
\hline
\end{tabular}

Table 4. Inter-set correlations between the two first axes of the RDA and the abiotic factors measured at Toropi River basin, southern Brazil.

\begin{tabular}{lcc}
\hline \multicolumn{1}{c}{ Axes } & $\mathbf{1}$ & $\mathbf{2}$ \\
\hline Air temperature & -0.87 & -0.09 \\
Electrical conductivity & -0.70 & 0.60 \\
Stream order & 0.26 & 0.73 \\
\hline
\end{tabular}

In such regions, streams tend to show great variability in abiotic factors through their courses, especially in river bed sediment grain size (Alan and Castillo, 2007), providing a high number of suitable habitats for the establishment of more diverse macroinvertebrate communities (Principe and Corigliano, 2006). In lowland courses, the occurrence of macrophytes can also be expressive (Sá et al., 2013). Aquatic vegetation represents one of the main factors providing habitat and refugia for macroinvertebrates, favoring an increment in richness (Taniguchi and Tokeshi, 2004). Besides, other factors vary along the altitudinal gradient, like stream width and depth, water turbidity and coverage of riparian vegetation (Vannote et al., 1980).

However, overall richness of some groups studied here is at times lower when compared to tropical climate regions (e.g. Savannah and Amazon regions; Table 2). Concerning genera richness, some aquatic insects are more diversified in tropical or subtropical climate regions, such as Ephemeroptera and Elmidae (Barber-James et al., 2008; Jäch and Balke, 2008). The relationship between warmer temperatures and higher richness are well known from the literature for many animal communities 
(e.g., Allen et al., 2002; Wiensa and Donoghueb, 2004; Mccain, 2005). On the other hand, Trichoptera, which is evolutionarily original from cold and temperate regions (Ross, 1967), tends to be more diverse in regions with similar conditions, as in southern Brazil, due to adaptive and historic factors. Thus, the results of this study corroborates trends suggested in previous studies that lotic ecosystems from temperate regions sustain richer communities of certain groups of macroinvertebrates than warmer regions (e.g., McKie et al., 2005; Floss et al., 2012).

The diversity patterns concerning the families representing EPT in the Neotropics were maintained in relation to studies conducted in other regions of the country (Bispo and Oliveira, 2007; RighiCavallaro et al., 2010). The Plecoptera is represented by six families in the Neotropics (Stark et al., 2009), but only two (Gripopterygidae and Perlidae) occur in Brazil (Froehlich, 2011); both recorded in this study. Fourteen families of Ephemeroptera are recorded in the Neotropics, ten of them in Brazil (Salles et al., 2004). In the study area only four families were recorded, and all of them were already assigned to the state (Pereira and De Luca, 2003; König et al., 2008; Siegloch et al., 2008; Milesi et al., 2009; Hepp et al., 2013). The families lacking are Polymitarcyidae, Euthyplociidae, Ephemeridae, Oligoneuriidae, Coryphoridae and Melanemerellidae). From the six families not found in the area, four (Ephemeridae, Oligoneuriidae, Coryphoridae and Melanemerellidae) are few diversified and/or more common in subtropical areas (Salles et al., 2004). The Trichoptera has 24 families recorded for the Neotropics (Flint et al., 1999), 16 in Brazil (Paprocki et al., 2004). In this study, ten families occurred. From the six families not found in the area, four (Anomalopsychidae, Atriplectidade, Limnephilidae, and Xiphocentronidae) are typical of warmer, tropical regions (states of Minas Gerais and Rio de Janeiro; Paprocki et al. (2004)). The other two (Odontoceridae and Sericostomatidae) had been registered during the 1980's in states of Santa Catarina and Paraná, which are similar in climate with Rio Grande do Sul, indicating that the occurrence of such families in the state is predictable.

The most diverse families in relation to number of genera in the Toropi River were Elmidae (eight genera), Baetidae, Leptohyphidae and Hydroptilidae (six each), which were also the most diverse in other regions of Brazil (Bispo and Oliveira, 2007; Righi-Cavallaro et al., 2010; Segura et al., 2012). Elmidae are abundant and diverse in many Brazilian streams (Segura et al., 2012), for their larvae are well-adapted to riffle areas and high levels of dissolved oxygen (Brown, 1987). Baetidae are found in many freshwater ecosystems (from riffles to temporary ponds), and even in highly impacted limnetic systems (Callisto et al., 2001). Hydroptilidae are generally found in stony substrate streams, and some genera of this family are scrapers and collector-gatherers, adhering to the substrate to feed (Stehr, 1987; Merritt and Cummins, 1996), making them typical of lotic areas. Similarly, Leptohyphidae nymphs are poor swimmers and therefore must gather to rocks or to the vegetation to feed (Stehr, 1987).

The most abundant genera in this study (Smicridea, Americabetis and Thraulodes) are also dominant in various Brazilian regions (CrisciBispo et al., 2007; Righi-Cavallaro et al., 2010). In southern Brazil they are also frequent (Spies et al., 2006; Siegloch et al., 2008). The caddisfly Smicridea is generally abundant in streams, occurring from headwaters to large rivers (Flint et al., 1999), and their individuals are typical of stony substrate streams (Spies and Froehlich, 2009), like the streams of this study. Thraulodes is a mayfly typical of low-order and well-preserved streams, living on rocks (Cardoso et al., 1997). Thus, the occurrence of this genus in the study area reflects not only its preference for the order of the streams sampled, but also the environmental condition of some of them. Many streams and tributaries in the Toropi River basin still present well-preserved banks. The other mayfly (Americabaetis) is also widely distributed and found in many habitats, from sites with riparian and aquatic vegetation to highly impacted ones (Siegloch et al., 2008; Domínguez et al., 2006). Despite Ephemeroptera be considered characteristic of 'clean' waters, Baetidae (the family which Americabaetis belongs to) is classified as 'sensitive' in biotic indexes (Hilsenhoff, 1988). This moderate sensitivity and tolerance possibly explains the elevated abundance of this genus in the study region.

The caddisfly Austrotinodes Schmid, 1955 and Celaenotrichia Mosely, 1934 are recorded for the first time in Rio Grande do Sul. To date, Austrotinodes had only been recorded in tropical and subtropical areas of the country, and Celaenotrichia had not been recorded for the southern region of Brazil (Paprocki et al., 2004). The elmid Genus M, which had only been recorded for the São Paulo state (Segura et al., 2011), is also a first record for Rio Grande do Sul. 


\subsection{Influence of abiotic factors on community composition}

The influence of climatic, spatial, and anthropogenic drivers on EPTC communities was observed, although it had been stronger on few genera. The positive relation of Smicridea with AT is better understood by analyzing its distribution in Brazil. Smicridea can be found in warmer regions of the country (Oliveira and Bispo, 2001; Pes et al., 2005; Souza et al., 2013), and some of its species (e.g., Smicridea truncata Flint, 1974) occur in the tropical Amazon region (Pes et al., 2008). Three genera were inversely related to stream order. Species of Camelobaetidius are sensitive to pollution and commonly found at well-preserved and coarser substrate sites (Buss and Salles, 2007), usual features of low-order streams. Paracloeodes can also be frequent in low-order sites (Salvarrey et al., 2014). Americabaetis, although a normally widely distributed genus, is also associated to the presence of riparian vegetation (Domínguez et al., 2006), which is usually better preserved in low-order stretches (Vannote et al., 1980). In fact, those conditions (coarser substrate, presence of riparian vegetation and lower pollution) are typical from higher elevations (Vannote et al., 1980).

Thraulodes was positively influenced by EC, despite being also found at well-preserved sites (Cardoso et al., 1997). High EC values are normally related to anthropic activities, like agriculture (Stewart et al., 2000), which is more common in low elevation areas (Lenat and Crawford, 1994), indicating that this genus might be tolerant to human activities. Therefore, the spatial distribution of both the fauna and abiotic drivers in this study is linked to the elevation gradient of the region. Modifications in abiotic community drivers in lotic ecosystems according to altitude are well known in literature, due to combining roles of watershed geology, climatic constraints and distribution of human activities (Miserendino, 2001; Jacobsen, 2004, 2008).

\section{Final Remarks}

The Toropi River basin hosts high diversity of genera of Ephemeroptera, Plecoptera, Trichoptera and Elmidae coleopterans in relation to other basins from Rio Grande do Sul and other states of Brazil. Although collections were temporally restricted, 52 genera were found, and three of them are new records for the state. The elevated number of genera found in the study area is due to the environmental heterogeneity of the streams located in slope areas, as observed in other studies (Floss et al., 2012; Sá et al., 2013). Additionally, it is verified that the elevation gradient of the study area affected climatic, anthropic and spatial drivers, such as air temperature, stream order and electrical conductivity, which, in turn, influenced the distribution of some genera (e.g., Camelobaetidius, Paracloeodes, Americabaetis, Smicridea and Thraulodes). Thus, this study evidences that streams from slope areas in the Southern Plateau (Planalto Meridional) deserve special attention from future aquatic conservation and assessment programs, for they host high levels of biodiversity.

\section{Acknowledgments}

The authors are grateful to MSc. Andrea Salvarrey and biologist Tiago Bertaso for their aid in the identification of Ephemeroptera individuals, and to doctors Luiz Ubiratan Hepp and Ana Emília Siegloch for providing important comments to the original manuscript. We thank the team of the Laboratório de Macroinvertebrados Aquáticos (UFSM), for aiding in field sampling and laboratory work. We also thank CAPES for the scholarship conceded to Bruna Marmitt Braun. This paper is part of the master dissertation of Bruna Marmitt Braun at UFSM.

\section{References}

ALLAN, JD. and CASTILLO, MM. 2007. Stream ecology: structure and function of running waters. 2nd ed. Netherlands: Springer. 436 p.

ALLEN, AP., BROWN, JH. and GILLOLY, JF. 2002. Global diversity, biochemical kinetics and the energetic-equivalce rule. Science, vol. 297, no. 5586, p. 1545-1548. PMid:12202828. http://dx.doi. org/10.1126/science. 1072380

ANGRISANO, EB. and KOROB, PG. 2001. Trichoptera. In FERNÁNDEZ, HR. and Domínguez, E., ed. Guía para Determinación de los Artrópodos Bentónicos Sudamericanos. San Miguel de Tucúman: Universidad Nacional de Tucumán/Faculdad de Ciencias Naturales/Instituto M. Lillo. p. 5-92.

BAPTISTA, DF., DORVILLÉ, LFM., BUSS, DF., NESSIMIAN, JL. and SOARES, LHJ. 1998. Distribuiçáo de comunidades de insetos aquáticos no gradiente longitudinal de uma bacia fluvial do sudeste brasileiro. Oecologia Brasiliensis, vol. 5, no. 1, p. 191207. http://dx.doi.org/10.4257/oeco.1998.0501.14

BARBER-JAMES, HM., GATTOLLIAT, JJ., SARTORI, M. and HUBBARD, MD. 2008. Global diversity of mayflies (Ephemeroptera, Insecta) in freshwater. Hydrobiologia, vol. 595, no. 1, p. 339-350. http:// dx.doi.org/10.1007/s10750-007-9028-y 
BARBOSA, FF., FERNANDES, AS. and OLIVEIRA, LG. 2013. Taxonomic key for the genera of Elmidae (Coleoptera, Byrrhoidea) occurring in Goiás state, Brazil, including new records and distributional notes. Revista Brasileira de Entomologia, vol. 57, no. 2, p. 149-156. http://dx.doi.org/10.1590/S008556262013005000004

BEMVENUTI, CE. 1998. Estrutura trófica. In SEELIGER, U., ODEBRECHT, C. and CATELLO, J., ed. Os ecossistemas costeiros e marinhos do extremo sul do Brasil. Rio Grande: Ecoscientia. 326 p.

BENETTI, JC., FIORENTINI, GL., CUETO, JAR and MIGUEL, RRP. 1998. Coleopterofauna Aquática na Floresta Estacional de São Francisco de Paula, RS, Brasil. Acta Biologica Leopoldensia, vol. 20, p. 91-101.

BESKOW, PR. 1984. A formação da economia arrozeira do Rio Grande do Sul. Ensaios FEE, vol. 4, no. 2, p. 55-84.

BISPO, PC. and OLIVEIRA, LG. 2007. Diversity and structure of Ephemeroptera, Plecoptera and Trichoptera (Insecta) assemblages from riffles in mountain streams of Central Brazil. Revista Brasileira de Zoologia, vol. 24, no. 2, p. 283-293. http://dx.doi. org/10.1590/S0101-81752007000200004

BISPO, PC., OLIVEIRA, LG., BINI, LM. and SOUSA, KG. 2006. Ephemeroptera, Plecoptera and Trichoptera assemblages from riffles in mountain streams of central Brazil: environmental factors influencing the distribution and abundance of immatures. Brazilian Journal of Biology, vol. 66, no. 2b, p. 611-622. PMid:16906293. http://dx.doi. org/10.1590/S1519-69842006000400005

BISPO, PC., OLIVEIRA, LG., CRISCI-BISPO, VL. and SILVA, MM. 2001. A pluviosidade como fator de alteração da entomofauna Bentônica (Ephemeroptera, Plecoptera e Trichoptera) em córregos do Planalto Central do Brasil. Acta Limnologica Brasiliensia, vol. 13, no. 2, p. 1-9.

BROWN, HP. 1987. Biology of riffle beetles. Annual Review of Entomology, vol. 32, p. 253-273. http:// dx.doi.org/10.1146/annurev.en.32.010187.001345

BUCKUP, L., BUENO, AAP., BOND-BUCKUP, G., CASAGRANDE, M. and MAJOLO, F. 2007. The benthic macroinvertebrate fauna of highland streams in southern Brazil: composition, diversity and structure. Revista Brasileira de Zoologia, vol. 24, no. 2, p. 294-301. http://dx.doi.org/10.1590/S010181752007000200005

BURIOL, GA., ESTEFANEL, V., CHAGAS, AC. and EBERHARDT, D. 2007. Clima e vegetação natural do estado do Rio Grande do Sul segundo o diagrama climático de Walter e Lieth. Ciência Florestal, vol. 17, no. 2, p. 91-100.

BUSS, DF., BAPTISTA, DF., NESSIMIAN, JL. and MARIANA, M. 2004. Substrate specificity, environmental degradation and disturbance structuring macroinvertebrate assemblages in Neotropical streams. Hydrobiologia, vol.
518, p. 179-188. http://dx.doi.org/10.1023/ B:HYDR.0000025067.66126.1c

BUSS, DF., BAPTISTA, DF., SILVEIRA, MP., NESSIMIAN, JL. and DORVILLÉ, LFM. 2002. Influence of water chemistry and environmental degradation on macroinvertebrate assemblages in a river basin in south-east Brazil. Hydrobiologia, vol. 481, no. 1-3, p. 125-136.

BUSS, D. and SALLES, FF. 2007. Using baetid species as biological indicators of environmental degradation in a Brazilian river basin. Environmental Monitoring and Assessment, vol. 130, p. 365-372. PMid:17106778. http://dx.doi.org/10.1007/s10661-006-9403-6

CALLISTO, M., MORETTI, M. and GOULART, M. 2001. Macroinvertebrados Bentônicos como ferramenta para avaliar a saúde dos riachos. Revista Brasileira de Recursos Hídricos, vol. 6, no. 1, p. 71-82.

CARDOSO, MCZ., HERNANDEZ, AMR. and AGUILERA, SM. 1997. Biological aspects of Ephemeroptera in rivers of southwestern Colombia (South America). In Taller Internacional sobre sistemática y Ecología de Ephemeroptera como Bioindicador de Calidad de Agua, 1997. Santiago de Cali, Colombia. p. 1-13.

COLWELL, RK. 2006. EstimateS: statistical estimation of species richness and shared species from samples. Version 8. Available from: <http://viceroy.eeb.uconn. edu/estimates $>$. Access in: 19 set 2013.

CRISCI-BISPO, VL., BISPO, PC. and FROEHLICH, CG. 2007. Ephemeroptera, Plecoptera and Trichoptera assemblages in two Atlantic Rainforest streams, Southeastern Brazil. Revista Brasileira de Zoologia, vol. 24, no. 2, p. 312-318.

DOMÍNGUEZ, E. and FERNÁNDEZ, HR. 2009. Macroinvertebrados Bentónicos Sudamericanos: sistemática y biología. Tucumán: Fundacion Miguel Lillo. $654 \mathrm{p}$.

DOMÍNGUEZ, E., MOLINERI, C., PESCADOR, ML., HUBBARD, MD. and NIETO, C. 2006. Ephemeroptera of South America. In ADIS, J., ARIAS, JR., RUEDA-DELGADO, G. and WANTZEN, KM., ed. Aquatic Biodiversity in Latin America (ABLA). Sofia-Moscow: Pensoft. 46 p. (vol. 2).

FERNANDEZ, MFS. and FONSECA, CRV. 2001. Estudo Taxonômico dos Psephenidae (Coleoptera: Byrrhoidea) da Amazônia Brasileira. Acta Amazonica, vol. 31, no. 3, p. 469-500.

FIDELIS, L., NESSIMIAN, JL. and HAMADA, N. 2008. Distribuição espacial de insetos aquáticos em igarapés de pequena ordem na Amazônia Central. Acta Amazonica, vol. 38, no. 1, p. 127-134. http:// dx.doi.org/10.1590/S0044-59672008000100014

FLINT, OS., HOLZENTHAL, RW. and HARRIS, SC. 1999. Catalog of the Neotropical Caddisflies (Insecta: Trichoptera). Columbus: Ohio Biological Survey. 239 p.

FLOSS, ECS., KOTZIAN, CB., SPIES, MR. and SECRETTI, E. 2012. Diversity of non-biting midge larvae assemblages in the Jacuí River basin, Brazil. 
Journal of Insect Science, vol. 12, no. 121, p. 1-33. http://dx.doi.org/10.1673/031.012.12101

FROEHLICH, CG. 2011. Checklist dos Plecoptera (Insecta) do Estado de São Paulo, Brasil. Biota Neotropica, vol. 11, no. 1, p. 601-606.

GALDEAN, N., CALLISTO, M. and BARBOSA, FAR. 2001. Biodiversity assessment of benthic macroinvertebrates in altitudinal lotic ecosystems of Serra do Cipó (MG, Brazil). Revista Brasileira de Biologia, vol. 61, no. 2, p. 239-248. http://dx.doi. org/10.1590/S0034-71082001000200006

GONÇALVES, FB. and MENEZES, MS. 2011. A comparative analysis of biotic indices that use macroinvertebrates to assess water quality in a coastal river of Paraná state, southern Brazil. Biota Neotropica, vol. 11, no. 4, p. 24-36. Available from: $<$ http://www. biotaneotropica.org.br/v11n4/en/abst ract?article+bn00411042011>.

HEPP, LU., MILESI, SV., BIASI, C. and RESTELLO, RM. 2010. Effects of agricultural and urban impacts on macroinvertebrates assemblages in streams (Rio Grande do Sul, Brazil). Zoologia, vol. 27, no. 1, p. 106-113. http://dx.doi.org/10.1590/S198446702010000100016

HEPP, LU., RESTELLO, RM., MILESI, SV., BIASI, C. and MOLOZZI, J. 2013. Distribution of aquatic insects in urban headwater streams. Acta Limnologica Brasiliensia, vol. 25, no. 1, p. 1-10. http://dx.doi. org/10.1590/S2179-975X2013005000014

HILSENHOFF, WL. 1988. Rapid field assessment of organic pollution with a family-level biotic index. Journal of North American Benthological Society, vol. 7 , no. 1, p. 65-68. http://dx.doi.org/10.2307/1467832

HUNDERTMARCK, IS. and MIORIN, VMF. 2001. Classificação das zonas agroecológicas na sub-bacia do rio Ibicuí-Mirim: adequação das culturas ao tipo de solo - RS. Geografia: Ensino e Pesquisa, vol. 11, p. 9-15.

JÄCH, MA. and BALKE, 2008. Global diversity of water beetles (Coleoptera) in freshwater. Hydrobiologia, vol. 595, no. 1, p. 419-442. http:// dx.doi.org/10.1007/s10750-007-9117-y

JACOBSEN, D. 2004. Contrasting patterns in local and zonal family richness of stream invertebrates along an Andean altitudinal gradient. Freshwater Biology, vol. 49, p. 1293-1305. http://dx.doi.org/10.1111/j.13652427.2004.01274.x

JACOBSEN, D. 2008. Tropical high-altitude streams. In DUDGEON, D., ed. Tropical stream ecology. San Diego: Elsevier. p. 219-256.

KILCA, VR. and LONGHI, JS. 2011. A composição florística e a estrutura das florestas secundárias no rebordo do Planalto Meridional. In SCHUMACHER, MV. and SOLON, J., org. A Floresta Estacional Subtropical: caracterização e ecologia no rebordo do Planalto Meridional. Santa Maria: Pallotti.

KÖNIG, R., SUZIN, CH., RESTELLO, RM. and HEPP, LU. 2008. Qualidade das águas de riachos da região norte do Rio Grande do Sul (Brasil) através de variáveis físicas, químicas e biológicas. Pan-American Journal of Aquatic Sciences, vol. 3, no. 1, p. 84-93.

LECCI, LS. and FROEHLICH, CG. 2007. Plecoptera. In FROEHLICH, CG., org. Guia on-line: identificação de larvas de insetos aquáticos do Estado de São Paulo. USP. Available from: <http://sites.ffclrp.usp. br/aguadoce/guiaonline>.

LEGENDRE, P. and GALLAGHER, E. 2001. Ecologically meaningful transformations for ordination of species data. Oecologia, vol. 129, no. 2, p. 271-280. http://dx.doi.org/10.1007/ s004420100716

LEGENDRE, P. and LEGENDRE, L. 1998. Numerical ecology. Amsterdam: Elsevier. 853 p.

LENAT, DR. and CRAWFORD, JK. 1994. Effects of land use on water quality and aquatic biota of three North Carolina piedmont streams. Hydrobiologia, vol. 294, no. 3, p. 185-199. http://dx.doi.org/10.1007/ BF00021291

MALONEY, KO. and WELLER, DE. 2011. Anthropogenic disturbance and streams: land use and land-use change affect stream ecosystems via multiple pathways. Freshwater Biology, vol. 56, p. 611-626. http://dx.doi.org/10.1111/j.13652427.2010.02522.x

MALUF, JRT. 2000. Nova classificação climática do Estado do Rio Grande do Sul. Revista Brasileira de Agrometeorologia, vol. 8, no. 1, p. 141-150.

MARIANO, R. and FROEHLICH, CG. 2007. Ephemeroptera. In FROEHLICH, CG., org. Guia on-line: identificação de larvas de insetos aquáticos do Estado de São Paulo. USP. Available from: <http:// sites.ffclrp.usp.br/aguadoce/guiaonline>.

MCCAIN, CM. 2005. Elevational gradients in diversity of small mammals. Ecology, vol. 86, no. 2, p. 366372. http://dx.doi.org/10.1890/03-3147

MCKIE, BG., PEARSON, RG. and CRANSTON, PS. 2005. Does biogeographical history matter? Diversity and distribution of lotic midges (Diptera: Chironomidae) in the Australian Wet Tropics. Austral Ecology, vol. 30, p. 1-13. http://dx.doi.org/10.1111/ j.1442-9993.2005.01408.x

MERRITT, RW. and CUMMINS, KW. 1996. An introdution to the aquatic insects of North America. Dubuque: Kendall/Hunt. 862 p.

MERRITT, RW., CUMMINS, KW. and BERG, MB. 2008. An Introduction to the Aquatic Insects of North America. 4th ed. Dubuque: Kendall Hunt Publishing.

MILESI, SV., BIASI, C., RESTELLO, RM. and HEPP, LU. 2009. Distribution of benthic macroinvertebrates in Subtropical streams (Rio Grande do Sul, Brazil). Acta Limnologica Brasiliensia, vol. 21, no. 4, p. 419-429.

MISERENDINO, ML. 2001. Macroinvertebrate assemblages in Andean Patagonian rivers and streams: environmental relationships. Hydrobiologia, vol. 444, p. 147-158. http://dx.doi. org/10.1023/A:1017519216789 
NIMER, E. 1990. Clima. In Institutlo Brasileiro de Geografia e Estatística - IBGE. Geografia do Brasil: regiăo Sul. Rio de Janeiro. 420 p.

OLIVEIRA, LG. and BISPO, PC. 2001. Ecologia de comunidades das larvas de Trichoptera Kirby (Insecta) em dois córregos de primeira ordem da Serra dos Pireneus, Pirenópolis, Goiás, Brasil. Revista Brasileira de Zoologia, vol. 18, no. 4, p. 1245-1252. http:// dx.doi.org/10.1590/S0101-81752001000400019

OLIVEIRA, LG., BISPO, PC. and SÁ, NC. 1997. Ecologia de Comunidade de insetos bentônicos (Ephemeropetra, Plecopetra e Trichoptera), em córregos do Parque Ecológico de Goiânia, Goiás, Brasil. Revista Brasileira de Zoologia, vol. 14, no. 4, p. 867-876.

PACIENCIA, GP., YOKOYAMA, E., BISPO, PC., CRISCI-BISPO, VL. and TAKEBE, IV. 2011. Ephemeroptera, Plecoptera e Trichoptera em Corredeiras de Riachos do Parque Estadual Intervales, Estado de São Paulo. EntomoBrasilis, vol. 4, no.3, p. 114-118.

PAPROCKI, H., HOLZENTHAL, RW. and BLAHNIK, RJ. 2004. Checklist of the Trichoptera (Insecta) of Brazil I. Biota Neotropica, vol. 4, no. 1, p. 1-22. http:// dx.doi.org/10.1590/S1676-06032004000100008

PASSOS, MIS., NESSIMIAN, JL. and DORVILLÉ, LFM. 2003a. Distribuição espaço-temporal da comunidade de Elmidae (Coleoptera) em um rio na Floresta da Tijuca, Rio de Janeiro, RJ. Boletim do Museu Nacional, vol. 509, p. 1-9.

PASSOS, MIS., NESSIMIAN, JL. and DORVILLÉ, LFM. 2003b. Life strategies in an Elmidae (Insecta: Coleoptera: Elmidae) community from a first order stream in the Atlantic Forest, southeasteam Brazil. Acta Limnologica Brasiliensia, vol. 15, p. 29-36.

PAULA, MC. and FONSECA-GESSNER, AA. 2010. Macroinvertebrates in low-order streams in two fragments of Atlantic Forest in different states of conservation, in the State of São Paulo (Brazil). Brazilian Journal of Biology, vol. 70, no. 3, p. 899909. PMid:21085795. http://dx.doi.org/10.1590/ S1519-69842010000400021

PEDRON, FA., POELKING, EL., DALMOLIN, RSD. and KLAMT, ACAE. 2006. A aptidão de uso da terra como base para o planejamento da utilização dos recursos naturais no município de São João do Polêsine - RS. Ciência Rural, vol. 36, no. 1, p. 105-112. http://dx.doi.org/10.1590/S010384782006000100016

PEREIRA, D. and DE LUCA, SJ. 2003. Benthic macroinvertebrates and the quality of the hydric resources in Maratá Creek basin (Rio Grande do Sul, Brazil). Acta Limnologica Brasiliensia, vol. 15, no. 2, p. 57-68.

PES, AMO., HAMADA, N. and NESSIMIAN, JL. 2005. Chaves de identificação de larvas para famílias e gêneros de Trichoptera (Insecta) da Amazônia Central, Brasil. Revista Brasileira de Entomologia, vol. 49, no. 2, p. 181-204. http://dx.doi.org/10.1590/ S0085-56262005000200002

PES, AMO., HAMADA, N. and SOARES, CC. 2008. Description of the last-instar larva and pupa and the bionomics of Smicridea (Smicridea) truncata Flint (Trichoptera: Hydropsychidae) in Central Amazonia, Brazil. Zootaxa, vol. 1732, p. 56-60.

PIRES, MM., KOTZIAN, CB., SPIES, MR. and NERI, DB. 2013. Diversity of Odonata (Insecta) larvae in streams and farm ponds of a montane region in southern Brazil. Biota Neotropica, vol. 13, no. 3, p. 259-267. http://dx.doi.org/10.1590/S167606032013000300028

PRIMEL, EG., ZANELLA, R., KURZ, MHS., GONÇALVES, FF., MACHADO, SO. and MARCHESAN, E. 2005. Poluição das águas por Herbicidas utilizados no cultivo do Arroz Irrigado na Região Central do Estado do Rio Grande do Sul, Brasil: predição teórica e monitoramento. Química Nova, vol. 28, no. 4, p. 605-609. http://dx.doi. org/10.1590/S0100-40422005000400010

PRINCIPE, RE. and CORIGLIANO, MC. 2006. Bentic, drifting and marginal macroinvertebrate assemblages in a low river: temporal and spatial variations and size structure. Hydrobiologia, vol. 553, p. 303-317. http://dx.doi.org/10.1007/s10750-0050694-3

QUADROS, FLF. and PILLAR, VP. 2002. Transiçôes floresta- campo no Rio Grande do Sul.: fitogeografia do Sul da America. Ciência \& Ambiente, vol. 24, p. 109-118.

RIGHI-CAVALLARO, KO., SPIES, MR. and SIEGLOCH, AE. 2010. Ephemeroptera, Plecoptera and Trichoptera assemblages in Miranda River basin, Mato Grosso do Sul State, Brazil. Biota Neotropica, vol. 10 , no. 2, p. 253-261.

ROBAINA, LE., TRENTIN, R., BAZZAN, T., RECKZIEL, EW., VERDEUM, R. and NARDIN, D. 2010. Compartimentação geomorfológica da Bacia Hidrográfica do Ibicuí, Rio Grande do Sul, Brasil: proposta e classificação. Revista Brasileira de Geomorfologia, vol. 11, no. 2, p. 11-23.

ROMERO, RM., CENEVIVA-BASTOS, M., BAVIERA, GH. and CASATTI, L. 2013. Community structure of aquatic insects (Ephemeroptera, Plecoptera, and Trichoptera) in Cerrado streams of Paraguay, Paraná, and São Francisco river basins. Biota Neotropica, vol. 13, no. 1, p. 97-107. http://dx.doi.org/10.1590/ S1676-06032013000100011

ROSENBERG, DM. and RESH, VH. 1993. Freshwater biomonitoring and benthic macroinvertebrates. New York: Chapman \& Hall. 488 p.

ROSS, HH. 1967. The evolution and past dispersal of the Trichoptera. Annual Review of Entomology, vol. 12, p. 169-206. http://dx.doi.org/10.1146/annurev. en.12.010167.001125

SÁ, RL., SANTIN, L., AMARAL, AMB., MARTELLO, AR. and KOTZIAN, CB. 2013. Diversidade de 
moluscos em riachos de uma região de encosta no extremo sul do Brasil. Biota Neotropica, vol. 13, no. 3, p. 213-221. http://dx.doi.org/10.1590/S167606032013000300024

SALLES, FF., SILVA, ER., HUBBARD, MD. and SERRÃO, JE. 2004. As espécies de Ephemeroptera (Insecta) registradas para o Brasil. Biota Neotropica, vol. 4, no. 2, p. 1-34. http://dx.doi.org/10.1590/ S1676-06032004000200011

SALVARREY, AVB., KOTZIAN, CBK., SPIES, MR. and BRAUN, BM. 2014. The influence of natural and anthropic environmental variables on the structure and spatial distribution along longitudinal gradient of macroinvertebrate communities in southern Brazilian streams. Journal of Insect Science, vol. 14, no. 13 , p. $1-23$.

SEGURA, MO., FONSECA-GESSNER, AA., SPIES, MR. and SIEGLOCH, AE. 2012. Water beetles in mountainous regions in southeastern Brazil. Brazilian Journal of Biology, vol. 72, no. 2, p. 311321. PMid:22735139. http://dx.doi.org/10.1590/ S1519-69842012000200012

SEGURA, MO., GESSNER, AAF. and TANAKA, MO. 2007. Composition and distribution of aquatic Coleoptera (Insecta) in low-ordem streams in the state of São Paulo, Brazil. Acta Limnologica Brasiliensia, vol. 19, p. 247-255.

SEGURA, MO., VALENTE NETO, F. and GESSNER, AAF. 2011. Chave de famílias de Coleoptera aquáticos (Insecta) do Estado de Sáo Paulo, Brasil. Biota Neotropica, vol. 11, no. 1, p. 1-16.

SIEGLOCH, AE., FROEHLICH, CG. and KOTZIAN, CB. 2008. Composition and diversity of Ephemeroptera (Insecta) nymph communities in the middle section of the Jacuí River and some tributaries, southern Brazil. Iheringia, vol. 98, p. 425-432. http:// dx.doi.org/10.1590/S0073-47212008000400002

SIEGLOCH, AE., POLEGATTO, CM. and FROEHLICH, CG. 2006. Segesta riograndensis, new genus and species of Atalophlebiinae mayfly from South of Brazil (Ephemeroptera: Leptophlebiidae). Zootaxa, vol. 1299, p. 35-43.

SILVA, ECD., MURAOKA, T., BUZETTI, S., VELOSO, MEDC. and TRIVELIN, PCO. 2006. Aproveitamento do nitrogênio $(15 \mathrm{~N})$ da crotalária e do milheto pelo milho sob plantio direto em Latossolo Vermelho de Cerrado. Ciência Rural, vol. 36, p. 739-746.

SOUZA, WRM., LIMA, LRC., PES, AMO. and PINHEIRO, U. 2013. Trichoptera (Insecta) from Pernambuco State, northeastern Brazil. Journal of Natural History, vol. 47, no. 45-46, p. 2905-2914.

SPIES, MR. and FROEHLICH, CG. 2009. Inventory of caddisflies (Trichoptera: Insecta) of the Campos do Jordão State Park, São Paulo state, Brazil. Biota Neotropica, vol. 9, no. 4, p. 1-8.

SPIES, MR., FROEHLICH, CG. and KOTZIAN, CB. 2006. Composition and diversity of Trichoptera (Insecta) larvae communities in the middle section of the Jacuí River and some tributaries, State of Rio Grande do Sul, Brazil. Iheringia. Série Zoologia, vol. 96, p. 389-398.

STARK, BP., FROEHLICH, CG. and ZUÑIGA, MC. 2009. South American Stoneflies (Plecoptera). In ADIS, J., ARIAS, JR., RUEDA-DELGADO, G. and WANTZEN, KM., ed. Aquatic Biodiversity in Latin America (ABLA). Sofia-Moscow: Pensoft. 154 p. (vol. 5).

STEHR, FW. 1987. Immature insects. Dubuqueque: Kendall/Hunt. 754 p.

STEWART, PM., BUTCHER, JT. and SWINFORD, TO. 2000. Land use, habitat and water quality effects on macroinvertebrate communities in three watersheds of a Lake Michigan as sociated marsh system. Aquatic Ecosystem Health and Management, vol. 3, p. 179-189.

TANIGUCHI, H. and TOKESHI, M. 2004. Effects of habitat complexity on benthic assemblages in a variable environment. Freshwater Biology, vol. 49, no. 9, p. 1164-1178. http://dx.doi.org/10.1111/ j.1365-2427.2004.01257.x

TER BRAAK, CJF. and ŠMILAUER, P. 2002. CANOCO: reference manual and CanoDraw for Windows User's guide. Software for Canonical Community Ordination (version 4.5). Ithaca: Microcomputer Power. 352 p.

VANNOTE, RL., MINSHALL., GW., CUMMINS, KW., SEDELL, JR. and CUSHING, CE. 1980. The River Continuum Concept. Canadian Journal of Fisheries and Aquatic Sciences, vol. 37, no. 1, p. 130137. http://dx.doi.org/10.1139/f80-017

WIENSA, JJ. and DONOGHUEB, MJ. 2004. Historical biogeography, ecology and species richness. Ecology \& Evolution, vol. 19, no. 12, p. 639-644. PMid:16701326. http://dx.doi.org/10.1016/j. tree.2004.09.011

YOKOYAMA, E., PACIENCIA, GP., BISPO, PC., OLIVEIRA, LG. and BISPO, PC. 2012. A sazonalidade ambiental afeta a composição faunística de Ephemeroptera e Trichoptera em um riacho de Cerrado do Sudeste do Brasil? Ambiência, vol. 8, no. 1, p. 73-84. http://dx.doi.org/10.5777/ ambiencia.2012.01.06

Received: 27 January 2014 Accepted: 08 July 2014 